\title{
Implementation of Micro-Climate Greenhouse for Hot and Arid Regions by Utilizing Geothermal Energy
}

\author{
Salih N Akour ${ }^{1 *}$, Farah Mohammed Alyassi ${ }^{2}$, Haya Khalfan Alshamsi ${ }^{2}$ and Afra Majid Alowais ${ }^{2}$ \\ ${ }^{1}$ Mechanical Engineering Department, The University of Jordan, Amman, Jordan \\ ${ }^{2}$ The University of Sharjah, College of Engineering, Sustainable and Renewable Energy Engineering Department, Emirate Al-Sharjah, UAE \\ *Corresponding Author: Salih N Akour, Mechanical Engineering Department, School of Engineering, Mechanical Engineering \\ Department, Amman, Jordan.
}

Received: September 24, 2019; Published: October 30, 2019

DOI: 10.31080/ASAG.2019.03.0704

\begin{abstract}
Underground water is one of the geothermal energy sources worldwide. The importance of this source becomes huge for hot and arid regions such as the Arabian Gulf States. Experimental study is carried to explore the opportunity of utilizing underground water as a cooling system for greenhouse. The experiment is carried in Emirate Al-Sharjah, UAE. Active control system is utilized for cooling the greenhouse by controlling underground water flowrate based on the greenhouse climate temperature. The underground water in the greenhouse model site is found not suitable for irrigation. Photovoltaic system is installed to provide the necessary power to operate all the greenhouse devices.
\end{abstract}

Keywords: Greenhouse; Hot and Arid Region; Micro-Climate; Geothermal Energy

\section{Introduction}

Cultivating crops in protected environment is called greenhouse agriculture. Such system, mechanically saves plants against harsh climate conditions like extreme temperature, relative humidity, etc. Greenhouse not only protects plants but also provide a control over the $\mathrm{CO}_{2}$ concentration. Cultivating off-seasonal crops becomes viable using greenhouse technology [1-3]. The greenhouse provide favorable microclimate for high productive farming and food security for regions that has harsh weather such as the Arabian Peninsula and Arabian Gulf Countries [4]. These regions are characterized by hot and arid climate. Many attempts are made by researchers all around the world to design a greenhouse that provides suitable climate for growing crops. Excellent summery for these researches work can be found in the recent review paper authored by Ghani., et al. [5].

Most of researchers' attempts are made by utilizing the available cheap resources. Some of these cheap and sustainable resources are the geothermal energy and solar energy. In Tunisia, Attar., et al. [6] developed heat exchanger that is partially suspended in the greenhouse air and the second part is buried under the ground of the greenhouse. During the day time the upper part of the heat exchanger will pump the excess heat to the ground heat exchanger to cool the greenhouse. At night the process is reversed, the stored heat in the ground heat exchanger will be pumped back to greenhouse air. This technique according to the researchers maintain the greenhouse air temperature at $20^{\circ} \mathrm{C}$ in the day time. Similar results are achieved by Boughanmi., et al. [7] through using a conical coil basket shaped heat exchanger that is installed underground to work as a heat sink. Their results show reduction of greenhouse temperature by $12^{\circ} \mathrm{C}$ during daytime. In northern region of Thailand, Mongkon., et al. [8] cultivated flowers, chilies and tomato in greenhouse utilizing underground horizontal tube heat exchanger. Through their experiment they manage to achieve a cooling capability of $74.84 \%$ in summer.

Ozgener and Ozgener $[9,10]$ implemented underground air tunnel systems that has U-shape to cool greenhouse in hot days in Turkey. Their study achieved results of reducing the greenhouse temperature by up to $4.2^{\circ} \mathrm{C}$, whereas the overall energy efficiency of $60.7 \%$, and a total average coefficient of performance of 10.09 .

The usage of Photovoltaic (PV) system has grown rapidly in the last decade. Many countries have used such systems to support agriculture by providing the needed power to run the greenhouse systems.

Nakoul., et al. [11] have carried out theoretical study using Matlab software to size the needed PV system for operating greenhouses. Yano.,et al. [12] recommended the use of Semi-transparent PV panels for areas with high solar radiation intensity. In Malaysia Al-shamiry., et al. [13] used PV solar panels for cooling a tropical greenhouse. They concluded its suitability to provide the required cooling energy load without using extra energy from the grid. In Turkey Yildiz., et al. [14, 15] implemented an earth-to-air exchanger with photovoltaic cells for $\mathrm{N}$-S oriented greenhouse. A reduction of $9{ }^{\circ} \mathrm{C}$ is achieved using combination of solar and geothermal energy compared to the outdoor ambient temperature. A similar combination of PV and Earth to Air Heat Exchanger is modeled in India by Nayak and Tiwari [16] for an even span E-W oriented 
greenhouse. Energy produced from the PV panels can be used to satisfy the ventilation and cooling loads making the method favorable for greenhouse located in remote areas.

In India, Sethi and Sharma [17] conducted experiments on Aquifer Coupled Cavity Flow Heat Exchanger System for cooling greenhouses in summer season and heating them on winter nights. The heat exchanger is a counter-flow air-water heat exchanger.

Subin., et al. [18] recommended that roof covered area of greenhouse should not exceed $50 \%$ of the total roof area as reduction of photosynthetically radiation since it may affect growth rates.

The objective of this study is to utilize underground water as heat sink to cool and irrigate greenhouse to cultivate vegetables and crops during summer in hot and arid regions. The experiment is conducted in Emirate of Al-Sharjah in UAE. It is known that Emirate Al-Sharjah is rich of underground water.

\section{Experimental model}

The greenhouse model is implement at a backyard of a school in downtown Sharjah City where underground well is available. The pore of the well is approximately $25 \mathrm{~m}$ deep and $1 \mathrm{~m}$ diameter. The piping system utilized is not insulated so heat is exchanged with the surrounding air. Schematic diagram of the greenhouse model made by SketchUp Program is shown in Figure 1. Sharjah Emirate is located at $25.3463^{\circ} \mathrm{N}, 55.4209^{\circ} \mathrm{E}$. In summer the sun rays are perpendicular on the Tropic of Cancer i.e. at $23^{\circ} \mathrm{N}$, so the sun ray is almost perpendicular at the solar noon on that location. Even span shape is selected. The size of the greenhouse model is $3 \times 3 \times 2.2 \mathrm{~m}^{3}$.

\section{Experimental setup}

The experimental setup consists of greenhouse for cultivating crops, pump for sucking underground water through insulted piping system and pass it through heat exchangers (radiators) that are placed inside the greenhouse very close to the ground as shown in Figure 1a. The underground water works as coolant fluid. The water passed through the radiator exits the greenhouse and injected back into underground through a pore located at a distance approximately $300 \mathrm{~m}$ far from the suction pump bore. The size and shape of the greenhouse is shown in Figure 1b. Set of flow control devices and temperature measurement devices are utilized. Also PV system is used to provide the need power to operate the greenhouse system devices. Ventilation fan placed near the roof of the greenhouse to suck the hot air and allow fresh air to flow into the greenhouse from a small window located in the north side of the greenhouse close to the ground. This will allow cooler air to flow into the greenhouse compared to the other sides of the greenhouse.

\section{Greenhouse construction}

An even span shape greenhouse model is build using steel frame covered with the polycarbonate as cladding materials, as in shown in Figure 2 [19]. Another steel frame that is overhanging above the roof of the greenhouse by $0.25 \mathrm{~m}$ is constructed to carry a shad-net made of polyethylene material. This overhanging material will partially shad the greenhouse and reduce the amount of solar irradiance pass to the greenhouse. A small corridor is made to ease the

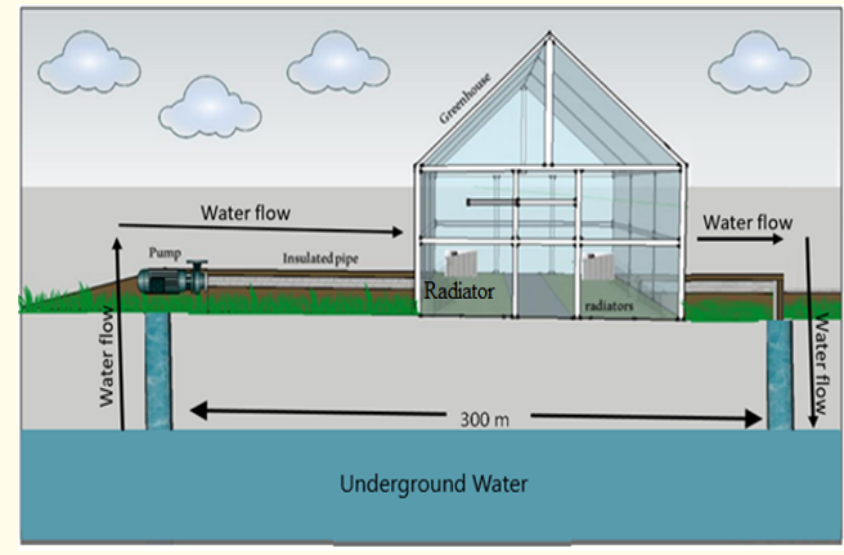

a

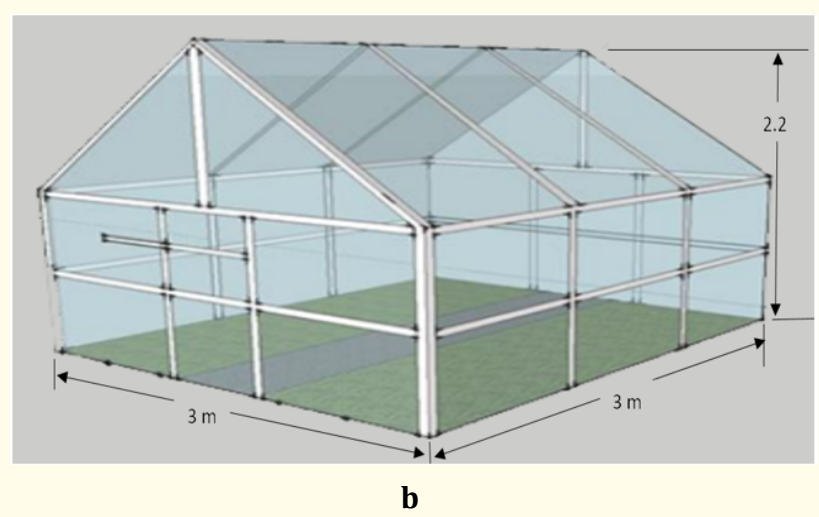

Figure 1: Schematic diagram for the greenhouse model, a) underground water flow diagram, b) size and shape of the greenhouse.

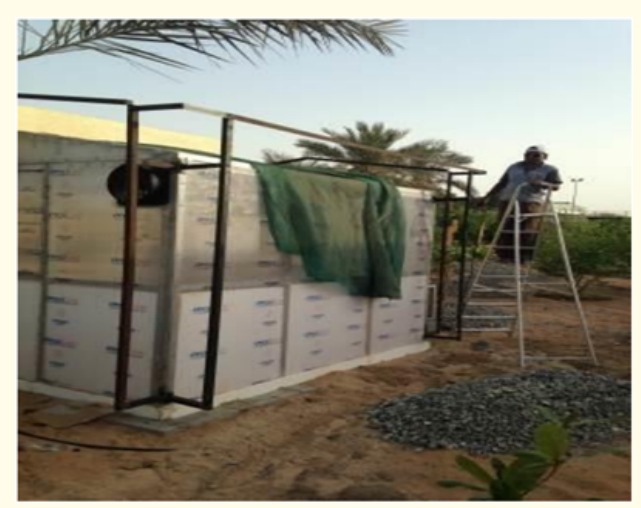

Figure 2: Greenhouse construction.

movement inside the greenhouse. Foam boards are placed inside the ground around the greenhouse backed with concrete bricks to thermally insulate the greenhouse ground from the surrounding. Furthermore, a silicon material is used to close any cracks in the building to maintain the cold air inside the green house.

\section{Temperature control}

Temperature controller is shown in Figure 3. This device controls the underground water pump. This device is set at certain temperature that is suitable for plants cultivation. So when the temperature of the greenhouse climate is higher than the set temperature the device will increase the cool underground water flow 
rate through the radiators (heat exchangers) that are placed inside the greenhouse to bring its climate to the set temperature. When the temperature is below the set temperature the temperature controller will stop the underground water flow through radiators. This active control system will maintain the proper climate needed for cultivation. The underground water enters the radiators at $32^{\circ} \mathrm{C}$ and set to exit at a maximum temperature of $36^{\circ} \mathrm{C}$.

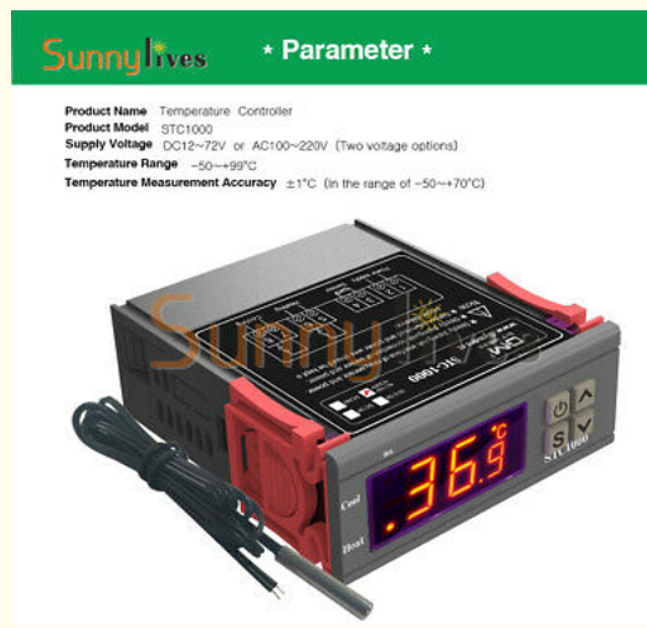

Figure 3: Photo of the temperature controller used in the greenhouse, Source: https://picclick.com/110V-10A-Mini-DigitalSTC-1000-All-purpose-Temperature-Controller-283216951780. html, accessed September 20, 2019.

\section{Irrigation system}

Water irrigation system controller is illustrated in Figure 4. It is easy and flexible to operation. It can be programed to control the time and amount of watering. The system has a standard set of programming options. This watering system helps keeping the plants roots and its soil of proper moisture. A soil moisture probe shown in Figure 5 is utilized to provide checking for soil moisture content. Drip irrigation is selected for plant watering. Municipality water is used for irrigation.

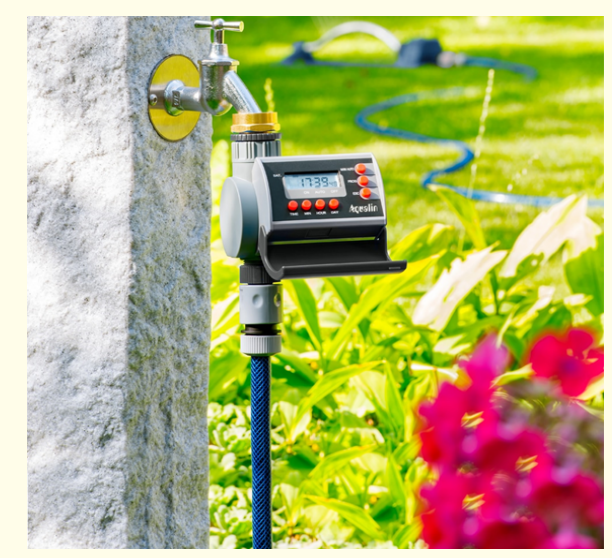

Figure 4: Water controller, Source: https://www.aliexpress.com/, accessed September 20, 2019.

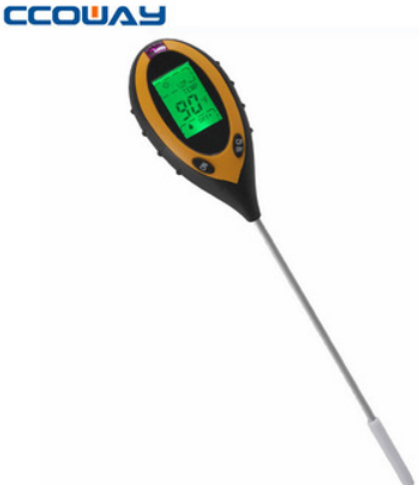

Figure 5: Photo of the soil moisture probe, Source: https://www.alibaba.com/ , accessed September 20, 2019.

\section{Cooling system}

Radiators are heat exchangers used to transfer thermal energy from one medium to another for the purpose of cooling or heating. The majority of radiators are constructed to function in automobiles, buildings, and electronics. Cross flow radiator is utilized in cooling the greenhouse as shown in Figure 6. Rather than manufacturing a radiator, used cars radiators and their fans are used for cooling and ventilation respectively. The radiators are connected in series arrangement. These fans are operated by 12 volt batteries that are charged using PV panels.

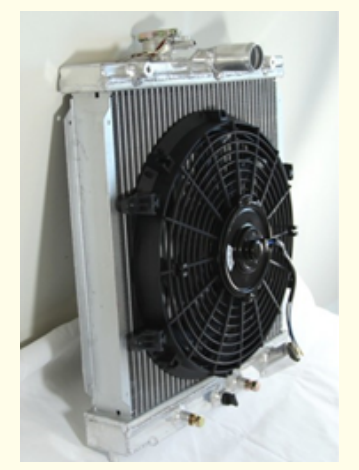

Figure 6: Photo of the radiator utilized in the greenhouse system. Source: https://www.speedyracer.com/96-00-HondaCivic-EK-DX-HX-LX-EX-SI-D16-B16-B18-RADIATOR-RAN12-RDFBracket-, accessed September 20, 2019.

\section{Heat exchanger calculation}

To determine the number of radiators needed for cooling the greenhouse, cooling heat analysis is made. The type of the radiator is cross-flow heat exchanger. The calculations are carried by considering the underground water inlet temperature of $32^{\circ} \mathrm{C}$ and the inlet air is $50^{\circ} \mathrm{C}$. These temperatures are considered based on the highest temperatures measures during summer season for both underground water and ambient temperatures. The system is assumed to have: Steady operating conditions, changes in the kinetic and potential energies of fluid are negligible, fluid properties for 
both air and water are constant. The main reason for such analysis is to select the proper pump size of underground water pump based on the maximum amount of flowrate needed.

Bases on the heat transfer calculations the heat exchanger area needed to achieve the heat transfer based on the conditions shown in Figure 7 is $0.5748 \mathrm{~m}^{2}$. The area of the radiator is $0.1211 \mathrm{~m}^{2}$, so the number of radiators needed are approximately 5 radiators. For detailed analysis for the heat exchanger see Appendix A1.

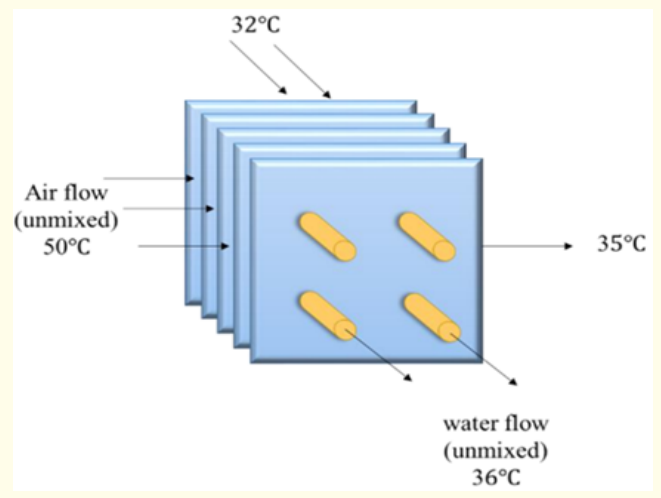

Figure 7: Schematic diagram for Cross-Flow heat exchanger.

\section{Solar PV sizing}

HOMER software package is utilizer to find out the size of the PV panels needed to operate the greenhouse system. Table 1 shows the list of appliances and their corresponding power needed. The appliances considered are underground water pump, Temperature and water flow rate controller, radiators' fans, ventilation fan. The total amount of energy needed watt-hour is 7092.7 which is the sum of the last column Energy per day in Table 1. This amount is the sum of energy demand needed as shown in the first row in Table 2. The demand details are shown in Table 2. Storage battery is sized based on one day demand. Summary of battery storage sizing is presented in Table 3. The number of batteries needed is 3 arranged in parallel.

\section{Results and Discussion}

After constructing the greenhouse that uses polycarbonate as a cladding material and using the underground water as a cooling system. Specific types of plants are selected for cultivation such as cucumbers, eggplant, tomatoes, zucchini and broccoli. Noting that plants are grown from seeds. Stages of plant growth are shown in figure 8.

\begin{tabular}{|l|c|c|c|c|c|}
\hline \multicolumn{1}{|c|}{ Appliance } & Rated wattage & Adjustment Factor & Adjustment wattage & Hours per day used & Energy per day \\
\hline $\begin{array}{l}\text { Underground water } \\
\text { pump }\end{array}$ & 1104 & 0.85 & 1298.8 & 3 & 3896.4 \\
\hline $\begin{array}{l}\text { Temperature and water } \\
\text { controller }\end{array}$ & 9.6 & 0.85 & 11.2 & 8 & 90.3 \\
\hline Five Car radiators' fans & 240 & 0.85 & 282.3 & 3 & 847.0 \\
\hline Two Ventilation fans & 160 & 0.85 & 188.2 & 12 & 2258.8 \\
\hline
\end{tabular}

Table 1: List of appliances used in the greenhouse and their load in watt.

\begin{tabular}{|c|l|c|}
\hline \multicolumn{3}{|c|}{ Demand } \\
\hline 1 & Total energy demand per day (watt-hour) & 7092.7 \\
\hline 2 & Total amp-hour demand per day (amp-hours) & 295.5 \\
\hline 3 & Maximum ac power requirement (watts) & 1513.6 \\
\hline 4 & Maximum ac power requirement (watts) & 1780.7 \\
\hline
\end{tabular}

Table 2: List of power demand and its components.
The temperature of both the ground water and ambient temperature are measured to assure suitability of the underground water for cooling the greenhouse. The temperature of the underground water and the ambient temperature in shad are recorded for 3 days, at three different times, at 7:49am, at 11:50am, and at 6:10 pm. Table 4 shows the outcome of this test. The results show that the temperature of underground water is suitable in cooling

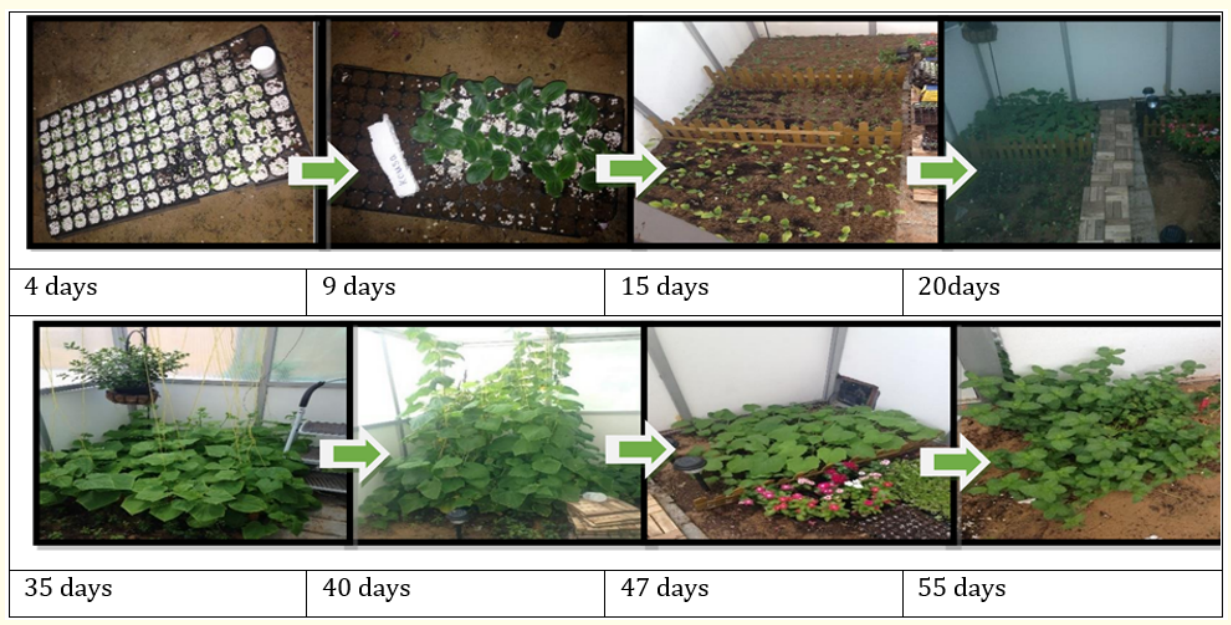

Figure 8: Growth stages for the cultivated plants in the greenhouse. 
the greenhouse. This indicates that underground water plays a role in cooling the greenhouse.

\begin{tabular}{|l|c|c|}
\hline \multicolumn{1}{|c|}{ Time } & $\begin{array}{c}\text { Outside } \\
\text { Temperature }\left({ }^{\circ} \mathbf{C}\right)\end{array}$ & $\begin{array}{c}\text { Underground Water } \\
\text { Temperature }\left({ }^{\circ} \mathbf{C}\right)\end{array}$ \\
\hline 12/07 & 31.8 \\
\hline 7:49 AM & 35.5 & 32.0 \\
\hline 11:50 AM & 44.3 & 31.9 \\
\hline 6:10 PM & 38.7 & 31.7 \\
\hline 13/07 \\
\hline 7:49 AM & 32.1 & 31.9 \\
\hline 11:50 AM & 41.3 & 31.8 \\
\hline 6:10 PM & 40.0 & 32.0 \\
\hline 14/07 & \\
\hline 7:49 AM & 36.4 & 32.2 \\
\hline 11:50 AM & 37.3 & 32.0 \\
\hline 6:10 PM & 39 & \\
\hline
\end{tabular}

Table 4: Sample of temperature data of underground water and ambient temperature in the shad collected in July 12,13 and 14.
Table 5 shows sample temperatures that were collected for three days on September 12, 13 and 14 for the greenhouse system. Temperatures of inlet groundwater, outlet ground-water, greenhouse space at three levels and, ambient in shad and direct sun are collected and recorded in Table 5. It is obvious from Table 5 that placing the radiators that work as heat exchangers inside the greenhouse, where the underground water is used as a working fluid in radiators, is capable of providing the proper climate for plants to grow. The temperatures inside the greenhouse are recorded at three different times, at 9:00am, at 12:00pm, and at 3:00 $\mathrm{pm}$. The measured temperatures inside the greenhouse are at three levels: near the ground, the mid-level of the greenhouse, and near the roof. It is obvious from Table 5 that the temperature difference achieved is approximately of average $25^{\circ} \mathrm{C}$ between the greenhouse climate and the ambient climate in direct sun where the greenhouse is located. The reference temperature is the air temperature near the ground in direct sun since the greenhouse is exposed to the direct sun. The temperature collected in the in direct sun is shown in the last column in Table 5. The accuracy of the temperature device is $+/-0.1^{\circ} \mathrm{C}$.

\begin{tabular}{|c|c|c|c|c|c|c|c|}
\hline \multirow{2}{*}{ Time } & \multirow{2}{*}{$\begin{array}{l}\text { Outside Temperature } \\
\left({ }^{\circ} \mathrm{C}\right) \text { in shad }\end{array}$} & \multicolumn{3}{|c|}{$\begin{array}{l}\text { Inside the greenhouse } \\
\text { Temperature }\left({ }^{\circ} \mathrm{C}\right)\end{array}$} & \multirow{2}{*}{$\begin{array}{c}\text { Outlet water } \\
\text { Temperature } \\
\left({ }^{\circ} \mathrm{C}\right)\end{array}$} & \multirow{2}{*}{$\begin{array}{c}\text { Outlet water } \\
\text { Temperature } \\
\left({ }^{\circ} \mathrm{C}\right)\end{array}$} & \multirow{2}{*}{$\begin{array}{l}\text { Outside Temperature } \\
\left({ }^{\circ} \mathrm{C}\right) \text { in direct Sun }\end{array}$} \\
\hline & & $\begin{array}{l}\text { Near the } \\
\text { Ground }\end{array}$ & $\begin{array}{l}\text { In the } \\
\text { Middle }\end{array}$ & $\begin{array}{l}\text { Near the } \\
\text { Roof }\end{array}$ & & & \\
\hline \multicolumn{8}{|l|}{$12 / 09$} \\
\hline 9:00 AM & 37.6 & 35.1 & 36.2 & 37.3 & 34.4 & 32.3 & \\
\hline $12: 00 \mathrm{PM}$ & 40.9 & 36.1 & 39.8 & 40.7 & 36.2 & 32.7 & 62.2 \\
\hline 3:00 PM & 37 & 34.4 & 35.6 & 36 & 34.6 & 32.5 & \\
\hline \multicolumn{8}{|l|}{$13 / 09$} \\
\hline 9:00 AM & 35.9 & 32.8 & 33.3 & 34.4 & 33.7 & 32.2 & \\
\hline $12: 00 \mathrm{PM}$ & 37.6 & 33.8 & 34.6 & 37.1 & 34.9 & 32.2 & 56.5 \\
\hline 3:00 PM & 38.7 & 34.7 & 37.8 & 38.1 & 34.4 & 32.7 & \\
\hline \multicolumn{8}{|l|}{$14 / 09$} \\
\hline 9:00 AM & 35.3 & 31.7 & 33.2 & 34.4 & 33.0 & 31.5 & \\
\hline $12: 00 \mathrm{PM}$ & 40.1 & 35.3 & 36.4 & 38.3 & 32.6 & 35.2 & 61.5 \\
\hline 3:00 PM & 40.7 & 34.6 & 36.9 & 37.6 & 32.8 & 35.2 & \\
\hline
\end{tabular}

Table 5: Greenhouse temperature testing using heat exchanger.

Underground water tests have been done to ensure the quality of water used in the greenhouse system and its' suitability for irrigation. Three different tests were made, the $\mathrm{PH}$ test to measure the acidity of water, water conductivity to measure the electrical conductivity and the TDS (Total Dissolved Solids) which is the total amount of mobile charged ions counting for minerals, salts or metals dissolved in water.

According to Table 6 the underground water is not suitable for irrigating crops [20]. The underground compositions may affect the devices, such as heat exchangers, which may cause a corrosion, so proper material should be used for manufacturing the radiators for large scale projects.

\begin{tabular}{|l|l|}
\hline \multicolumn{2}{|l|}{ Underground water test } \\
\hline Water composition & Water inlet to the radiator \\
\hline Water conductivity $(\mathrm{ms} / \mathrm{cm})$ & 3.95 \\
\hline TDS $(\mathrm{mg} / \mathrm{L})$ & 1975 \\
\hline PH & 7.68 \\
\hline Where TDS $(\mathrm{mg} / \mathrm{L})=0.5 \times 1000 \times \mathrm{xEC}(\mathrm{mS} / \mathrm{cm})$ \\
\hline
\end{tabular}

Table 6: Underground water analysis.

\section{Conclusion}

Greenhouse cooled by underground water as working fluid was constructed. The system is controlled using active control system that adjust itself based on the greenhouse temperature for cooling and soil moisture for irrigation. 
The inlet water to the radiators is ranging between $30-32^{\circ} \mathrm{C}$ all over the year, that makes it suitable to provide proper climate inside the greenhouse. The experiment proofs the suitability of the underground water as coolant working fluid for the greenhouse.

The water analysis shows that underground water is not suitable for irrigation in the location where the model greenhouse is installed.

Since the initial investment in constructing the greenhouse is relatively high, a strategic type of crops should be cultivated to make such investment worth it.

\section{Appendix A: Heat exchanger analysis}

The mass flow rate of air is measured for car radiator's fans and it is found to be $0.1699 \mathrm{~kg} / \mathrm{sec}$. Also the mass flow rate of underground water is measures using 5 Liter container. It took the underground water 33 seconds to fill the 5 Liters container.

$\dot{m}=\rho V$

$\dot{m}=995 * \frac{5 \mathrm{~L}}{33 \mathrm{sec}} * \frac{1 \mathrm{~m}^{3}}{1000 \mathrm{~L}}=0.151 \mathrm{~kg} / \mathrm{s}$

\section{Properties}

$-\mathrm{CV}$ (air) $=718 \mathrm{~J} / \mathrm{kg} \cdot \mathrm{K}$

- CP (water $)=4178 \mathrm{~J} / \mathrm{kg} . \mathrm{K}$

The rate of heat transfer of the underground water can be calculated as the following

$$
\begin{aligned}
& Q_{\text {water }}=\dot{m} * C_{p} * \Delta T \\
& Q_{\text {water }} \cdot \dot{\cdot}=0.151 * 4178 *(36-32) \\
& Q_{\text {water }}=2523.5 \text { watt }
\end{aligned}
$$

The rate of heat transfer of the air passing through the radiator can be calculated as the following

$$
\begin{aligned}
& \dot{Q_{\text {alr }}}=\dot{m} * C_{p} * \Delta T \\
& \dot{Q_{\text {alr }}}=0.1699 * 718 *(50-35) \\
& \dot{Q_{\text {alr }}}=1829.8 \mathrm{watt}
\end{aligned}
$$

The total surface area of the car radiator tubes $\mathrm{A}_{\mathrm{i}}$ can be calculated as the following

$$
\begin{aligned}
& A_{i}=n * \pi * D_{i} * L \\
& A_{i}=35 * 3.14 * 0.0285 * 0.3048 \\
& A_{i}=0.955
\end{aligned}
$$

$\mathrm{n}$ is the number of turns in the radiator, $\mathrm{D}^{\mathrm{i}}$ is the inner diameter of the radiator pipe and $\mathrm{L}$ is the turn length.

The overall heat transfer coefficient is

$$
U=\frac{\dot{Q}}{A_{i} * F * \Delta T_{m}}
$$

Where $\mathrm{F}$ the correction factor, $\mathrm{A}^{\mathrm{i}}$ is the tube surface area and $\Delta \mathrm{T}_{\mathrm{m}}$ is the mean temperature difference.

The mean temperature difference can be determined from the following equation

$$
\begin{aligned}
\Delta T_{m} & =\frac{\Delta T_{1}-\Delta T_{2}}{\ln \left(\frac{\Delta T_{1}}{\Delta T_{2}}\right)} \\
\Delta T_{m} & =\frac{15-4}{\ln \left(\frac{15}{4}\right)} \\
\Delta T_{m} & =8.32{ }^{\circ} \mathrm{C}
\end{aligned}
$$

$\Delta T_{1}$ is the difference between the average ambient temperature and the greenhouse inside design temperature.

$\Delta T_{2}$ is the difference between the average ambient temperature and the greenhouse inside design temperature.

is the difference between the average ambient temperature and the greenhouse inside design temperature. $\Delta T 2$ is the difference

$$
\begin{aligned}
& P=\frac{t_{2}-t_{1}}{T_{1}-t_{1}} \\
& P=\frac{36-32}{50-32}=0.22 \\
& Z=\frac{T_{1}-T_{2}}{t_{2}-t_{1}} \\
& Z=\frac{50-35}{36-32}=3.75
\end{aligned}
$$

Where $\mathrm{T}_{1}$ is the ambient temperature, $\mathrm{T}_{2}$ is the greenhouse design temperature, $t_{1}$ is the underground water inlet temperature, $t_{2}$ is the underground water outlet temperature.

From Figure $\mathrm{A} 1$ for $\mathrm{P}=0.22$ and $\mathrm{Z}=3.75$, the correction factor $(\mathrm{F})$ $=0.83$.

The overall heat transfer coefficient is

$$
\begin{aligned}
U & =\frac{\dot{Q}}{A_{i} * F * \Delta T_{m}} \\
U & =\frac{2523.5}{0.955 * 0.83 * 8.32} \\
U & =382.56 \frac{W}{K * m^{2}}
\end{aligned}
$$

The required number of the car radiators

$$
\begin{aligned}
& \dot{Q_{\text {air }}}=U * A * \Delta T_{m} \\
& A=\frac{Q_{\text {air }}}{U * \Delta T_{m}} \\
& A=\frac{1829.8}{382.56 * 8.32} \\
& A=0.5748 \mathrm{~m}^{2}
\end{aligned}
$$

Where the area of the car radiator $=0.1211 \mathrm{~m}^{2}$. So, $0.5748 / 0.1211$ $=4.747$. That's mean, five car radiators should be placed.

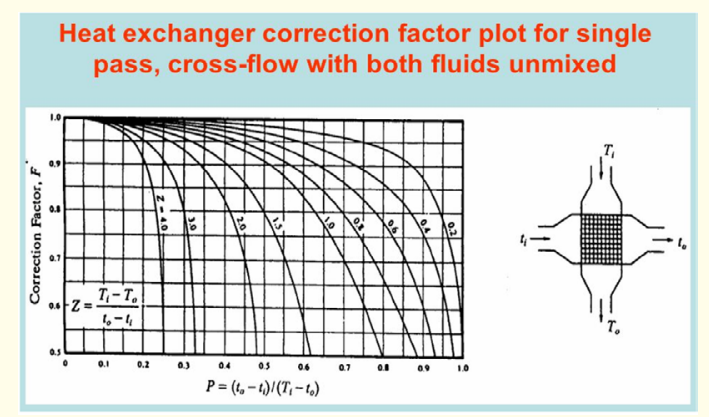

Figure A1: Correction factor. Source: http://images.slideplayer. com/7/1637582/slides/slide_33.jpg. 


\section{Bibliography}

1. Fatnassi H., et al. "Simulation of Climatic Conditions in FullScale Greenhouse Fitted with Insect-Proof Screens". Agricultural and Forest Meteorology 118.1 (2003): 97-111.

2. Sethi VP., et al. "Design and Evaluation of Modified Screen Net House for Off-Season Vegetable Raising in Composite Climate". Energy Conversion and Management 50.12 (2009): 3112-3128.

3. Benli H. "A Performance Comparison between a Horizontal Source and a Vertical Source Heat Pump Systems for a Greenhouse Heating in the Mild Climate Elaziğ, Turkey". Applied Thermal Engineering 50.1 (2013): 197-206.

4. Russo G., et al. "Environmental Analysis of Geothermal Heat Pump and Lpg Greenhouse Heating Systems". Biosystems Engineering 127 (2014): 11-23.

5. Ghani Saud., et al. "Design Challenges of Agricultural Greenhouses in Hot and Arid Environments - a Review". Engineering in Agriculture, Environment and Food 12.1 (2019): 48-70.

6. Attar I., et al. "Experimental Study of an Air Conditioning System to Control a Greenhouse Microclimate". Energy Conversion and Management 79 (2014): 543-553.

7. Boughanmi H., et al. "Thermal Performance of a Conic Basket Heat Exchanger Coupled to a Geothermal Heat Pump for Greenhouse Cooling under Tunisian Climate". Energy and Buildings 104 (2015): 87-96.

8. Mongkon S., et al. "Cooling Performance and Condensation Evaluation of Horizontal Earth Tube System for the Tropical Greenhouse". Energy and Buildings 66 (2013): 104-111.

9. Ozgener L and O Ozgener. "An Experimental Study of the Exergetic Performance of an Underground Air Tunnel System for Greenhouse Cooling". Renewable Energy 35.12 (2010): 28042811.

10. Ozgener $\mathrm{O}$ and L Ozgener. "Exergoeconomic Analysis of an Underground Air Tunnel System for Greenhouse Cooling System". International Journal of Refrigeration 33.5 (2010): 995-1005.

11. Nakoul Z., et al. "Optimization of a Solar Photovoltaic Applied to Greenhouses". Physics Procedia 55 (2014): 383-389.

12. Yano a., et al. "Development of a Greenhouse Side-Ventilation Controller Driven by Photovoltaic Energy". Biosystems Engineering 96.4 (2007): 633-641.

13. Al-Shamiry., et al. "Design and Development of a Photovoltaic Power System for Tropical Greenhouse Cooling”. American Journal of Applied Sciences 4.6 (2007): 386-389.

14. Ylldiz A., et al. "Energetic Performance Analysis of a Solar Photovoltaic Cell (Pv) Assisted Closed Loop Earth-to-Air Heat Exchanger for Solar Greenhouse Cooling: An Experimental Study for Low Energy Architecture in Aegean Region". Renewable Energy 44 (2012): 281-287.
15. Yildiz, A., et al. "Exergetic Performance Assessment of Solar Photovoltaic Cell (Pv) Assisted Earth to Air Heat Exchanger (Eahe) System for Solar Greenhouse Cooling". Energy and Buildings 43.11 (2011): 3154-3160.

16. Nayak $S$ and GN Tiwari. "Theoretical Performance Assessment of an Integrated Photovoltaic and Earth Air Heat Exchanger Greenhouse Using Energy and Exergy Analysis Methods". Energy and Buildings 41.8 (2009): 888-896.

17. Sethi VP and SK Sharma. "Greenhouse Heating and Cooling Using Aquifer Water”. Energy 32.8 (2007): 1414-1421.

18. Subin MC., et al. "Analysis of Materials Used for Greenhouse Roof Covering-Structure Using Cfd". IOP. Conference Series: Materials Science and Engineering. IOP Publishing (2018).

19. Cossu M., et al. "Solar Radiation Distribution inside a Greenhouse with South-Oriented Photovoltaic Roofs and Effects on Crop Productivity". Applied Energy 133 (2014): 89-100.

20. Home-Hydro-Systems. "Ph/Tds/Ppm Levels for Vegetables" (2019).

\section{Volume 3 Issue 11 November 2019}

(C) All rights are reserved by Salih N Akour., et al. 